\title{
Sejarah Politik Republik Islam Iran Tahun 1905-1979
}

\section{Wisnu Fachrudin Sumarno* \\ UIN Sunan Kalijaga}

Jl. Laksda Adisucipto, Sleman, Daerah Istimewa Yogyakarta 55281

\begin{tabular}{l|l|l} 
Submitted: $15^{\text {th }}$ Marc 2020 & Revised: $12^{\text {th }}$ May 2020 & Accepted: $1^{\text {st }}$ July 2020
\end{tabular}

\begin{abstract}
Iran is an Islamic country that is much discussed both in its history and political system. In Iran religion is the most Shiite followers. In the history of the establishment of the Iranian state the political system of Iran has been much like a monarchical system starting from Persia, Safavid dynasty to the Qajar regime, then continuing with an authoritarian military system during the Reza Shah Pahlevi after conquering the Qajar Regime until his son Muhammad Reza Pahlevi, and finally Theo-democracy with Waliyat al Faqih since the Iranian revolution in 1979 led by Ayyatullah Khumaeni. This study uses historical research methods and political approaches.
\end{abstract}

Keywords: Change, Politics, the Islamic Republic of Iran

\begin{abstract}
Abstrak Iran merupakan negara Islam yang banyak dibicarakan baik dalam sejarah maupun sistem perpolitikannya. Negara Iran merupakan negara penganut paham syiah yang paling besar. Sejarah berdirinya negara Iran dan sistem politik kekuasaan Iran hampir seperti sistem monarki mulai dari Persia, dinasti Safawiyah hingga rezim Qajar, kemudian berlanjut dengan sistem militer yang otoriter pada masa Reza Shah Pahlevi sesudah menaklukkan Rezim Qajar sampai putranya Muhammad Reza Pahlevi, dan terakhir Theo-demokrasi dengan Waliyat al Faqih semenjak terjadinya revolusi Iran pada tahun 1979 yang dipimpin oleh Ayyatullah Khumaeni. Penelitian ini menggunakan metode penelitian sejarah dan pendekatan politik.
\end{abstract}

Kata Kunci: Perubahan, Politik, Republik Islam Iran

\section{PENDAHULUAN}

Republik Islam Iran negara yang secara geografis termasuk di Kawasan Timur Tengah. Iran merupaka negara yang telah melalui rentang sejarah yang Panjang. Mulai dari abad ke 6, Iran dahulu dikenal dengan Persia yang menjadi salah satu imperium terbesar di dunia selain Romawi. Selama itu pula Iran berhasil membangun peradabannya hingga di akui sebagai salah satu bangsa yang paling berperadaban dalam sejarah. Iran 
termasuk bangsa yang diperhitungkan dalam kancah perpolitikan dunia (Mikail dan Fatoni, 2019: 2) Iran modern pewaris pola institusi, negara, agama, dan kesukuan dari dinasti Safawiyah. Era modern bermula tampilnya rezim Qajar yang meraih kekuasaan setelah melewati periode anarkis dan pergolakan kesukuan untuk merebut kekuasaan Iran. Rezim ini tak pernah terkonsolidasikan. Rezim baru tersebut sama sekali tidak pernah mencapai pancaran legitimasi yang sebelumnya telah menyinari pemerintahan Safawiyah dan tidak pernah menegakkan kekuasaanya secara penuh. Ia merupakan rezim memusat yang lemah yang menyerupai beberapa dinasti pendahulunya lantaran berhadapan dengan faktor-faktor kesukuan propinsial yang kuat dan rezim independensi keagamaannya sangat tinggi (Lapidus, 1999: 31-32).

Pemerintah pusat dinasti Qajar merupakan pemerintah istana yang terlalu lemah untuk mengembangkan secara efektif sistem perpajakan di Iran. Sementara itu kekuasaan tokoh- tokoh agama semakin luas pada abad delapan belas sampai abad sembilan belas ulama Iran mencapai tingkat otonomi yang tidak tertandingi oleh masa-masa pemimpin sebelumnya yang kuat. Otoritas keagamaan ulama dikenal sebagai mujtahid atau penerjemah hukum-hukum agama. Dikembangkan secara luas bahwasanya mereka memiliki hak mengambil keputusan secara independen dan hak menafsirkan permasalahan agama berdasarkan pencapaian spiritual dan intelektual mereka (Satori, 2012:64-65).

Sejak Revolusi Islam Iran 1979 yang dipimpin oleh Ayatullah Khomeini. Iran mengukir sejarah baru dalam lingkup sejarah politiknya, menjadi republik islam dengan sistem Waliyat Al Faqih sebagai sistem pemerintahannya. Sistem politik Iran menampilkan corak yang khas dalam pemikiran dan sistem politik islam dengan kepemimpinan negara yang dipegang oleh para ulama (Mullah). Sistem Waliyat Al Faqih merupakan ijtihad politik dari Ayatullah Khomeini yang didasarkan pada doktrin Imamah dalam syiah Imamiah. Keberhasilan revolusi islam 1979 ini cukup mempengaruhi bangkitnya kesadaran politik dan rasa percaya diri bangsa-bangsa muslim di dunia(Kadir, 2015: 2). Keterpakuan hanya pada fenomena di kawasan Timur Tengah itulah, menurut Hefner, yang menyebabkan munculnya kesalahpahaman yang fatal tentang relasi antara Islam dan politik. Pada awalnya umat islam cenderung menolak demokrasi kerena muncul dari barat (Hefner, 2005:XI-XII) permasalahan yang terjadi karena kebebasan individual untuk berekpresi yang biasa berporos pada isu-isu sosial barat seperti hak-hak kaum gay dan kesetaraan total gender (Adhib dan Qomari, 2018:20). Ronald Inglehart menegaskan bahwa dunia islam dan barat sebenarnya sama-sama mendukung politik demokrasi (Chehabi, 1991; Samsul Riza, 2011: 31). 
Iran merupakan sebuah bangsa dengan pemerintahan dinasti yang berlangsung selama 25 abad yang disokong oleh kekuatan Amerika Serikat dan Inggris akhirnya dapat tumbang dengan kekuatan masa yang dipelopori oleh para Mullah. Walhasil, Iran kemudian menjadi negara syiah pertama yang mendasarkan bentuk dan sistem pemerintahan negaranya pada konsep politik syiah Imamiah. Keberhasilan negara Iran hari ini menjadi salah satu bangsa yang cukup diperhitungkan oleh Inggris dan Amerika Serikat (selanjutnya disingkat AS) pada khususnya (Kadir,2015: 2). Revolusi Islam Iran 1979 juga mengubah konstelasi politik dan pertahan keamanan Iran (Smith, 2007; Abdmolaei, 2013). Jatuhnya Shah Reza Pahlevi membuat AS kehilangan langkah kemudahan untuk mengeksploitasi Iran. Terbukti Revolusi Islam Iran telah memutus peluang Amerika mendapat kontrak pembelian senjata seperti terjadi di era Shah Reza, sementara Inggris selaku sekutu Amerika tidak punya lagi akses ke ladng-ladang minyak di Khuzhistan, barat daya Iran (Khazim dan Hamzah 2007:35; Salehi-Isfahani, 2009).

Yang menarik dari Republik Islam Iran adalah komitmen negara dan pemerintah dalam menjalankan syari'at Islam tetapi sekaligus juga berusaha mencari bentuk demokrasi dalam pemerintahan maupun dalam sistem politik. Dalam sistem ekonomi, Iran berusaha untuk menerapkan prinsip-prinsip syar'ah dalam berekonomi. Sebagai contoh pemerintah Iran secara total mengkonversi sistem bank konvensional menjadi sepenuhnya bank Islam atau bank syari'ah. Pemerintah Iran juga berusaha untuk menjalin hubungan dagang terutama dengan negaranegara Muslim. Sistem negara dan pemerintahan, Iran melakukan model ideologization of religion untuk membentuk suatu religious ideology. Menurut Geiger, ideologi adalah suatu sistem gagasan tentang realitas sosial, yang diartikulasikan dengan konsustensi internal dan dielaborasi secara logis atas dasar asumsi-asumsi awal sehingga membentuk korpus tertulis, bebas dari pemikiran orang yang dapat dijadikan rujukan dan dapat menjadi dasar penafsiran, komentar dan indoktrinas. Ideologsasi Islam menurut Ali Merad berarti merumusklan kandungan Islam dalam bentuk norma dan nilai mengenai tatatan sosial-politik (akbar, 2017:104).

\section{METODE PENELITIAN}

Penelitian ini menggunakan metode sejarah (Sugeng, 2015:76). Metode sejarah guna menemukan data yang otentik dan dapat dipercaya, serta usaha sintesis atas data semacam itu menjadi kisah sejarah yang dapat dipercaya. Pengumpulan sumber buku dan jurnal untuk mengkaji apakah sumberr-sumber yang diperoleh dalam tahap heuristic dapat digunakan dalam penelitian yang kita lakukan atau tidak untuk mencari 
kebenaran dalam sejarah, sejarawan dihadapkan dengan kebutuhan untuk membedakan apa yang benar, apa yang tidak benar, apa yang mungkin, dan apa yang meragunan atau mustahil (Sjamsuddin, 1996: 1331). Metode penelitian sejarah ini fokus dalam menganalis pada masalah sejarah politik Republik Islam Iran. pendekatan ilmu politik juga digunakan karena untuk membantu dalam mengidentifikasi fokus permasalahan (Dudung, 2011:7).

\section{HASIL DAN PEMBAHASAN}

\section{Sejarah Republik Islam Iran}

Sejarah adalah pemaparan tentang kehidupan, aktivitas manusia dimasa lalu di suatu tempat tertentu. Kaitannya dengan sejarah Islam, hal itu mulai dari sejarah diturunkannya wahyu, yang sampai kini perjalanan Islam demikian berkembang ke berbagai Negara, dan salah satunya adalah Republik Islam Iran. Berdirinya Iran tidak terlepas dari sejarah kerajaan Safawi yang pernah jaya terutama di abad pertengahan. Kerajaan Safawi berperan dominan dalam menghidupkan dan menyebarkan paham Syiah sehingga sampai sekarang Iran menjadi basis utama mazhab Syiah (Rais,2015:274).

Gerakan Safawiyah yang didirikan oleh Syaikh Safi Al Din (12521334) seorang sufi sunni yang menjadi guru agama yang lahir dari sebuah keluarga Kurdi di IranUtara, juga mewakili sebuah kebangkitan islam popular yang menentang dominasi militer yang meresahkan dan bersifat eksploitaf. Sekalipun demikian tidak seperti beberapa gerakan lainya, gerakan Safawiyah memprakarsai penaklukan Iran dan mendirikan sebuah dinasti baru yang berkuasa dari 1501-1722. Pendiri mengawali gerakannya dengan seruan untuk memurnikan dan memulihkan kembali ajaran islam. Putranya yang bernama Sadr Al Din yang memimpin tharikat tersebut sejak 1334-1391, menjadikan sebuah organisasi yang secara politik dan hirarkis sangat sensitive sehingga menjadi organisasi yang cukup kaya. Ia adalah pemimpin tharikat yang mengklaim sebagai keturunan nabi. Ia menyebarkan keluarganya di Ardabil memperlengkapi mereka dengan beberapa sekolah dan tempat tinggal, memperluas kegiatan pergerakan misionarisnya. Ia mengorganisir hirarki para mursyid yan mengepalai tharikat, dan para khalifah yang merupakan agenya, dan mengepalai para misionaris, asisten, murid, dan anggota baru (Lapidus,1999:440).

Pada tahun 1501 Isma'il menduduki Tabriz dan menyatakan dirinya sebagai syah Iran. Ismail, selama masa kepemimpinannya menaklukan seluruh wilayah Iran yang lainya. Ketika imperium Usmaniyah, yang menjadi rivalnya bergerak kearah barat untuk merebut Anatoli Timur 
dan imperium Syaibaniyah bergerak ke arah Timur untuk mengambil alih kekuasaan atas wilayah Transoxania sampai sejauh sungai Oxsus. Ismail memperkokoh beberapa wilayah perbatasan yang sampai sekarang ini tetap sebagai wilayah Iran. Beberapa wilayah perbatasan tersebut membagi Timur Tengah menjadi sejumlah wilayah Turki Usmani yang terpisah-pisah, wilayah kultur muslim Iran dan sejumlah wilayah kultur Muslim Asia Tengah. Beberapa persaingan politik telah memencilkan Imperium Usmani dari kultur Islam di Iran, dan memperkuat sebuah perbedaan kultur, yang tengah berkembang antara Iran dan Asia tengah (Lapidus,1999:443-444).

Sejumlah problem pembangunan kembali negara dan masyarakat Iran adalah sangat besar. Pergolakan politik yang berlangsung dalam beberapa abad telah menggangu infrastruktur pemerintahan imperial yang memusat. Ekonomi pertanian dan produksi perkotaan telah dirusak oleh invansi nomadik. Kemerosotan ekonomi memperkecil sumbersumber utama suatu pemerintahan pusat. Berkurangnya populasi petani juga memperkecil jumlah tentara cadangan bagi suatu pemerintahan pusat. Problem utama negara Safawiyah adalah upaya mengkonsolidasikan otoritas keagamaan syiah dan kekuatan militer dan administrasi pemerintahan pusat terhadap sejujmlah uymaq Qizilbas yang secara nyata telah menaklukan Iran. Dibawah kekuasaan Safawiyah, Iran sungguh- sungguh diorganisir menjadi sejumlah wilayah kepemimpinan uymaq yang berkuasa atas klan-klan, dan persekutuan, kesukuan, dan beberapa kota dan desa. Misalnya, Mausillus, yang semula merupakan penguasa-penguasa regionaldi Syiria Utara dan Anatolia Timur, menguasai sejumlah teritorial yang luas di Iran Barat. Ustalju memperluas kekuasaanya dari negeri asalnya di Jilan sampai ke Azarbaijan dan wilayah pegunungan Eibruz. Beberapa kepala uymaq menjalankan sejumlah jabatan di dalam pemerintahan Safawiyah yang menerima berbagai subsidi, jatah infantry, tentara, pendapatan pajak, dan hak ekonomi yang menjadikan diri mereka semakin berpengaruh (Lapidus, 1999:444).

Jatuhnya safawi dari kekuasaan pada tahun 1722 setengah abad ketidak stabilan dan kekacauan politik mengiringi dan pada tahun 1779 naikntya tahta suku Qajar. Meskipun menggunakan gelar "bayangan tuhan di bumi", tidak pernah menuntut sanksi-sanksi keagamaan atau mengaku menyimpang dari garis imam, meningkatkan kesempatan fuqaha untuk melembagakan lebih lanjut otoritas keagamaanya. Mereka menjamin pengaruhnya dengan membuat taqlid pada seorang mujtahid yang hidup atas semua orang beriman, tidak pandang kedudukan dan posisinya dalam masyarakat. Mereka tidak ragu-ragu menggunaakan 
perangkat paksa untuk melaksanakan pandangan-pandangannya dan menindas pihak lain yang mungkin menyangkal, yang berarti menantang, posisinya sebagai satu-satunya eksponen agama dan pelindungnya terhadap segala macam " inovasi". Namun dalam hal ini terdapat catatan yang berguna bahwa akibat sentralisasi pemimpin keagamaan tidak bermaksud "memodernasi" agama nasional, sebagaimana dipertahankan secara keliru oleh sebagian orang. Selama lebih dari setengah abad Sembilan belas, perhatian ulama bukanlah bangsa. Kebijakan keagamaanya bukanlah kebijakan nasional, ataupun dimaksudkan untuk itu. Perlu juga ditekankan di sini bahwa fuqaha tidak "diangap pemimpin bangsa". Untuk mengaitkan dengan aktivitasaktivitas kelompok pada masa itu suatu jenis ideologi NasionalisModernis, sebenarnya sama sekali menyesatkan dan anakronistik (Esposito,1990:154-155).

Berlawanan dengan pandangan yang biasa dipegangi, ulama di Iran Qajar, atau bahkan sebelum itu tidak membentuk suatu kelas khasnya sendiri yang seragam yang secara ideologis kohesif dengan mengikat kesetiaan-kesetiaan dan loyalitas. Kelompok-kelompok internal, perbedaan pandangan keagamaan, konflik-konflik berbagai kepentingan yang sering kali mengubah sebagian perhatian ulama dari keagamaan murni ke pertimbangan-pertimbangan ekonomi dan politik, dengan serius telah membagi-bagi jajaranya. Abad 19, ketika kaum mujtahid muncul sebagai sebuah kelompok kekuatan yang aktif, para ulama pada umumnya membentuk perserikatan yang terikat longgar tidak dengan gambaran yang diputuskan dengan jelas.

Sejumlah orang di antaranya memiliki tanah dan bersama-sama memakai kepentingan dengan kelas yang memiliki tanah serta pedagangpedagang kaya. Sebagian berhubungan dengan keluarga raja atau dengan kepala-kepala suku. Banyak yang memegangi janji-janji pemerintah, termasuk posisi imam jamaah yang kuat, dan menerima gaji dari pejabat-pejabat negara, para pelindung raja dan pribadi-pribadi yang kaya. Dengan demikian pula ulama termasuk jajaranya bukan hanya fuqaha, melainkan juga para filosof dan teolog spekulatif, kaum mistik dari segala macamnya yang membentuk tatanannya masing-masing dengan organisasi-organisasi hirarkis yang terpisah, "penyimpangpenyimpang" yang memimpin suatu kebinekaan gerakan yang sedikit banyak aktif secara terbuka.

Unsur-unsur yang tidak puas dari dalam berbagai kelompok itu seringkali membangun jaringan komunikasi dan perangkat yang berbelitbelit untuk mengangkat pandangan-pandangan atas sainganya. Sebuah sistem persekutuan yang bijak yang sangat terinci, sedikit banyak 
berumur pendek, menarik perlindungan beberapa anggota kuat dari kelas-kelas yang sedang berkuasa yang memiliki vested interest umum. Suatu tema penting berhasil mencapai kekuasaan pada abad 19 di kalangan kelompok-kelompok dan pribadi-pribadi yang mewakili berbagai lapisan struktur sosial. Hal itu berasal dari suatu kensepsi lama tentang agama dan undang-undang keagamaan sebagai perubahan yang secara progresif evolusioner dan terus berlangsung (Esposito,1990:155156).

Ketegangan ulama dengan penguasa meningkat yang disebabkan intervensi Eropa yang memodifikasi posisi Qajar. Campur tangan bangsa Eropa terhadap Iran datang pertama kali dan mengukuhkan pengaruh mereka dengan persaingan antara kekuatan-kekuatan Eropa. Hal ini yang membangkitkan Qajar untuk memodernisasi, memperkuat perangkat kenegaraan, dan mereformasi pendidikan dengan membangun Perguruan Tinggi Teknik Dar al-fanun, serta mengorganisasi kembali pasukan kavaleri dengan membentuk Brigade Cossack. Reformasi tersebut membentuk strata baru pemikir moderenisasi Islam dan intelektual pendidikan barat yang cenderung terhadap medernisasi Iran sebagai satu-satunya cara efektif untuk melawan kekuatan asing dan untuk memperbaiki kondisi kehidupan sebagian besar masyarakat. Kejadian ini memicu timbulnya banyak perlawanan dari kaum intelektual dan ulama terhadap pengaruh asing dalam pemerintahan. Ada beberapa perlawanan penting yang terjadi pada masa pemerintahan Qajar, pertama, munculnya gerakan tembakau pada tahun 1891-1892 dipimpin Marja' Ayatullah al Uzma Mirza Hasan Shirazi.

Gerakan ini bertujuan untuk menghilangkan akses dunia barat yang menyebabkan turut campur dalam urusan internal Iran. Kedua, revolusi konstitusi Iran pada tahun 1905-1906 berhasil mengakhiri kekuasaan absolut raja. Hal ini disebabkan karena adanya protes dari para pedagang dan kaum ulama terhadap menguatnya pengaruh dari barat. Revolusi konstitusi ini adalah hasil dari kerjasama antara kaum pedagang bazar, ulama, cendekiawan, bangsawan pemilik tanah dan sejumlah kepala suku yang mewakili mereka di dalam majelis (parlemen), sebuah badan yang dibentuk setelah terjadi revolusi ini untuk ikut menjalankan roda pemerintahan bersama raja (Satori, 2012:65-67).

Pada tahu 1905-1911 terjadi krisis konstitusional yang menimbulkan penyatuan aspek-aspek fundamental masyarakat Iran, membangkitkan kekuatan gerakan nasionalisme awal, serta perlawanan terhadap intervensi asing, tetapi Iran, seperti kebanyakan negara muslim lainya, masih tetap mengalami pengaruh imperealisme barat. Ketiga, terjadinya pemberontakan-pemberontakan lokal yang disebabkan oleh tekanan 
yang terus menerus dari para gubernur lokal, para ulama dan intelektual modern. Iran hampir terbelah oleh Rusia dan Inggris diambang keruntuhan. Tahun 1925 Reza Syah Pahlevi berhasil memimpin Brigade Cossack melakukan kudeta menggulingkan kekuasaan raja terakhir Qajar (Satori, 2012:67-68).

Iran mengalami proses pembentukan negara bangsa yang serupa dengan proses berlangsungnya di Turki dan sejumlah negara lainya. Negara menjadi motor ekonomi dan perkembangan kebudayaan menurut model barat. Namun berbeda dengan Turki, penopang utama bagi rezim Pahlevi merupakan golongan menengah, Pahlevi juga mengembangkan angkatan bersenjata baru yang lebih kuat. Ulama banyak yang mendukung pengambil alihan kekuasaan oleh Pahlevi guna memulihkan monarki yang kuat untuk meredam kekuatan asing (Satori, 2012:69).

Kebijakan modernisasi yang digagas selama pemerintahan Reza Shah (1925-1941) dan dilanjutkan oleh puteranya, Shah terakhir, Muhammad Reza Pahlevi, mengakibatkan tumbuhnyakekuatan-kekuatan sosial baru yang mencemaskan kelompok-kelompok sosial tradisional. Menjelang akhir tahun 1970-an, kelas menengah kaya yang besar, generasi muda modern dan perempuan yang aktif di sektor publik, kelas pekerja industri dankelas miskin baru dari perkampungan kumuh, dan penghuni liar mendominasi pemandangan ini. Kecuali kaum miskin, kebanyakan kelompok mendapat keuntungan dari kemajuan ekonomi ini, menikmati status sosial yang tinggi dan kualitas hidup yang unggul. Akan tetapi, otokrasi Shah mencegah dengan gigih lapisan-lapisan sosial yang sedang berkembang ini untuk berpartisispasi dalam proses politik. Kebencian mereka memuncak ketika kelompok-kelompok sosial tradisional yang telah lebih lama eksis yang terdiri dari pedagang, kelas menengah urban, para ulama, dan orang-orang yang mengabdi pada lembaga-lembaga Islam-juga mengalami frustasi yang disebabkan strategi modernisasi dianggap merusak kepentingan ekonomi dan status sosial mereka (Asep, 2011:38).

Selama 25 tahun lebih pemerintahan otokrasi, semua partai politik sekuler dan LSM telah dinetralkan. Serangan tiba-tiba yang didukung Amerika pada 1953 telah menghancurkan gerakan-gerakan nasionalis dan komunis; persatuan-persatuan dagang disusupi oleh polisi rahasia SAVAK. SAVAK merupakan organisasi intelejen yang didirikan oleh Shah berkat bantuan CIA dan Mossad, organisasi intelejen Israel, dengan tujuan untuk memperkuat pemerintahan Shah pada tahun 1957 dan dibubarkan sampai dengan meletusnya revolusi Islam Iran pada tahun 1979. Pada masa Shah Mohammad Pahlevi, SAVAK merupakan salah 
satu kekuatan intelejen yang ditakuti oleh oposisi, karena SAVAK tidak segan untuk melakukan penganiayaan dan penahanan terhadap musuh politik (kiki, 2019:140); publikasi-publikasi disensor dengan ketat, dan sangat sedikit LSM yang tersisa. Organisasi-organisasi gerilya bawah tanah, salah satunya organisasi gerilya Fida'iyan Marxis

Mujahidin Islam Radikal, mengorganisasi banyak ketidaksepakatan politik, namun aktivitas mereka terbatas hanya pada operasi-operasi militan. Aktivisme mahasiswa tetap dibatasi hanya dalam politik kampus atau antar kampus. Singkatnya, entitas politik sekuler secara organisatoris terpasung. Meski demikian, tidak seperti kekuatankekuatan sekuler, lembaga ulama memiliki kapasitas kelembagaan yang tak terhingga nilainya dan secara hierarkis membawahi lebih dari 10.000 masjid, husayniyya (kelompok kecil penegak agama), hawzeh, dan asosiasiasosiasi yang bertindak sebagai alat komunikasi vital di kalangan kelompok revolusi.

Kelompok muda Islamisme, baik laki-laki maupun perempuan, bersama anggota ulama muda membentuk mediasi antara ulama dan masyarakat, sementara ulama struktural memfasilitasi pembuatan kebijakan yang integratif dan alur sistematis tentang peraturan dan informasi sehingga kebijakan tingkat tinggi dapat menyebar dari masjidmasjid ke para aktivis dan publik secara umum. Tidak tersedianya ruang alternatif yang memadai, kapasitas lembaga yang lemah dan ambiguitas yang mencolok di keseluruhan lembaga Negara mendorong ulama muncul di atas semua para pesaingnya. Kepemimpinan itu berhutang pada peristiwa revolusi yang berakhir relatif cepat sehingga hanya tersisa sedikit waktu untuk melakukan perdebatan atau menumbuhkan ketidaksepakatan atau untuk memberikan peluang munculnya gerakangerakan sosial lain pemimpin alternatif lain.

Gerakan Islam yang baru muncul tahun 1970-an berubah dengan cepat menjadi sebuah bentuk negara. "Islamisasi" menyebar luas setelah kemenangan Revolusi Islam dan diselenggarakan secara luas dari atas oleh negara Islam. Hal ini termanifestasi dalam pendirian wilayatul faqih (pemerintahan ulama, sistem hukum Islam, kebijakan-kebijakan yang membatasi ruang kaum perempuan, praktik-praktik, dan lembagalembaga budaya "Islam") (Kiki, 2019:140-141).

Pada awal-awal setelah revolusi, wanita banyak terikat oleh nilai-nilai Islam termasuk kewajiban mengenakan cadar. Namun dengan berjalannya waktu dan keinginan sebagian masyarakat Iran yang tidak ingin seperti itu dengan demonstrasi, akhirnya peraturan mengenakan cadar di cabut. Kenyataannya sekarang dapat di lihat, walau wajib mengenakan jilbab dan penutup aurat, tampil modis tidak dilarang. 
Perkembangan berikutnya kaum wanita mendapat peran aktif dan lebih luas. Ketika memasuki tahun 1990-an semakin banyak perempuan yang mengikuti pemilihan untuk menjadi anggota perlemen, yang pada gilirannya memperjuangkan isu-isu yang berkaitan dengan perempuan. Seperti adanya amandemen undang-undang tentang perceraian dan warisan, mengatur hak yang sama antara laki-laki dan perempuan (Esposito, 1999:88).

\section{Sistem politik Republik Islam Iran}

Islam datang membawa 5 perubahan seperti yang di katakan Musthafa Subba'I yaitu pertama bidang aqidah dan keagamaan, yang menyangkut paut dengan soal-soal keagamaan seluruhnya, termasuk soal akhlak, Kedua bidang falsafah dan ilmu pengetahuan yang meliputi segala cabang ilmu pengetahuan dan kebudayaan, ketiga bidang kesastraan dan kesenian, yeng meliputi seluruh soal kepujanggaan, kesusteraan dan kesenian, keempat bidang hukum dan perundang-undangan, yang meliputi segala soal hukum yang berlaku dalam masyarakat, baik pidana atau perdata ataupun hukuman-hukuman lainya dan terakhir bidang politik kenegaraan, yang meliputi segala soal-soal mengenai teori-terori kenegaraan dan praktek-praktek pemerintah. Lima bidang ini yang di contoh dan dilakukan dalam revolusi negara Islam Iran (Zainal, 1977:74). Aliran atau ideologi gerakan pra revolusi di iran secara garis besar dapat diidentifikasi dalam empat golongan yaitu: Nasionalis-Sekular, Marxisme-Komunis, Islam-Revolusioner Atau Sosialis, Dan IslamFundamentalis (Anjar,2014:192)

Paradigma baru mengenai sistem pemerintahan Iran karena revolusi islam yang terjadi. Sistem politik dan bentuk negara Iran berubah, dari sebuah monarki absolut menjadi sebuah republik Islam. Perbedaan yang paling mencolok dai antara keduanya, jika sebelum revolusi Iran merupakan sebuah negara sekuler, maka Iran pasca revolusi menjadi negara Theo-demokrasi yang didominasi kaum Mullah (Satori, 2012:159).

Waliyat al faqih merupakan sistem pemerintahan Republik Islam Iran yang diatur berdasarkan prinsip-prinsip pemerintahan Waliyat Al Amr, dan kepemimpinan agama. Kontitusi Iran, Undang-Undang Dasar harus menyiapkan lahan lagi bagi seorang Faqih yang memenuhi persyaratan yang diakui sebagi pemimpin oleh rakyat. Pengatur urusan-urusan adalah di tangan orang-orang alim tentang Allah, yang terpercaya dalam urusan yang menyangkut apa yang di halalkan dan diharamkan Allah.

Sebagai kewajiban Islam yang sejati, untuk mencegah setiap penyelewengan oleh berbagai organ negara dan tugas-tugas Islam yang hakiki (Satori, 2012:69). Konsep Wilayat Al Faqih merupakan suatu bagian 
yang tercantum dalam konstitusi negara Republik Islam Iran. Seperti tercantum dalam undang-undang dasar Republik Islam Iran dikatakan dalam pasal 107 konstitusi 1979 disebutkan pada prinsipnya mengesahkan Ayatullah Khumaeni sebagai wilayat al faqih, marja'taqlid yang terkemuka dan sekaligus sebagai pemimpin revolusi Islam Iran (Undang, 2014:94).

Pemegang kedaulatan tertinggi adalah Allah SWT dalam hiraki kekuasaan system Waliyat Al faqih, sedangkan pemegang kekuasaan penuh dipegang oleh Imam Mahdi yang nashi diyakini dalam masa ghaib kubra dan pelaksana tugas selama kegaiban Imam Mahdi adalah wali faqih. Struktur pemerintahan dalam Waliyat Al faqih terlihat sintesa konsep demokrasi modern ala barat dan sistem politik Imamah ala syiah imamiah. Hal ini terlihat pada konsep trias politika dalam pelaksanaan pemerintahan serta mengakomodir sistem demokrasi dengan pemilihan atau referendum.

Selain itu, sistem Imamah Syiah terlihat jelas dengan sentralik kekuasaan pada pemimpin spiritual. Kekuasaan dalam pemerintahan Waliyat Al faqih dipegang oleh seorang fakih yang dinilai memiliki keunggulan dibangding fakih-fakih yang lainya. Fakih yang memegang kekuasaan disebut Rahbar atau pemimpin spiritual. Jabatan ini dipegang selama seumur hidup kecuali kalau Rahbar dinilai menyimpang oleh Majelis ahli dari hukum Islam dan konstitusi. fungsi Rahbar merupakan penentu akhir dari segala keputusan yang diambil serta untuk menyelesaikan segala konflik yang terjadi pada lembaga-lembaga pemerintahan yang ada di bawahnya (Kadhir,2015:9).

Konsep trias politika digunakan dalam pembagian kekuasaan system Waliyat Al faqih. Kekuasaan legislatif dijalankan oleh tiga Lembaga yang memiliki tugas yang berbeda satu dengan yang lain. Tiga Lembaga itu adalah :

Majelis Shura al Islam, majelis ini berfungsi sebagai parlemen yang terdiri dari 270 anggota yang dipilih langsung oleh rakyat untuk masa jabatan 4 tahun. Majelis ini golongan minoritas seperti Zoroaster, Yahudi, Kristen, dan etnik Armenia yang mendapatkan jatah satu anggota di parlemen. Shiraya Nighaban (dewan perwalian), dewan ini diberikan tugas utama untuk menjamin agar keputusan-keputusan parlemen tidak mengabaikan ajaran Islam atau prinsip-prinsip konstitusi. Anggotanya terdiri dari 6 orang fuqaha yang diangkat oleh Rahbar dan 6 pakar hukum yang ahli dalam berbagai cabang hukum yang diusulkan oleh dewan kehakiman tertinggi nasional. Majelis al Khubreqan (majelis ahli), tugasnya hanyalah memilih atau memberhentikan Rahbar, serta mengontrol Rahbar dalam menjalankan tugasnya sebagai wakil dari Imam Mahdi. Majelis ini 
terdiri dari 73 ulama senior yang dipilih langsung oleh rakyat dalam sebuah pemilihan umum (Kadhir,2015:11).

Sistem Waliyat Al faqih kekuasaan eksekutif, kekuasaan presiden berada dibawah kekuasaan Rahbar dalam kekuasaan tertinggi negara. Presiden dipilih langsung oleh rakyat dalam sebuah pemilihan umum untuk masa jabatan 4 tahun, dan hanya bisa dipilih kembali hanya untuk satu periode berikutnya,Walaupun presiden memegang kekuasaan eksekutif, tapi kebijakan-kebijakannya dapat ditolak oleh rahbar, jika rahbar memandang bahwa kebijakan presiden tersebut bertentangan dengan ajaran Islam dan konstitusi.

Kekuasaan yudikatif tertinggi dipegang oleh dewan kehakimam tertinggi nasional atau mahkamah agung yang diangkat oleh Rahbar sesuai dengan UU konstitusi Republik Islam Iran. Mahkamah agung membawahi pengadilan tinggi untuk wilayah provinsi dan pengadilan rendah untuk wilayah kota atau distrik tertentu. Hakim, jaksa penuntut umum, dan kepala-kepala pengadilan harus berasal dari ahli-ahli hukum Syiah. Khusus Lembaga-lembaga hukum non syiah atau non muslim jaksa dan hakimnya berasal dari ahli-ahli hukum mazhab dan agama masing-masing (Kadhir,2015:12).

Selain terdapat instrument-instrumen yang dikenal di sebuah pemerintahan negara, Republik Islam Iran mempunyai beberapa bentuk dewan yang menjadikan keunikan dalam sistem pemerintahan Republik Islam Iran, dewan-dewan tersebut ialah: (Kadhir,2015:13). pertama, Dewan revolusi yang bertugas sebagai pasukan pengawal revolusi atau Pasdaran. Kedua dewan politik dan ekonomi revolusi yang dihubungkan dengan masjid-masjid yang tersebar di seluruh Republik Islam Iran. Ketiga, Pemimpin agama yang ditempatkan di masjid-masjid berfungsi sebagai administrator lokal. Mereka bertugas menyediakan makanan, pakaian, dan bantuan lainya kepada masyarakat yang kurang mampu, menjalankan pengadilan di tingkat lokal, mengumpulkan zakat dan khumus, serta berfungsi sebagai pemimpin Pasdaran lokal di daerahnya.

Sejarah Iran sebelum terbentuknya Republik Islam Iran dimulai dari dinasti Safawiyah yang kemudian di runtuhkan dan diambil alih oleh dinasti Qajar yang memimpin dengan bantuan barat dan banyak menggunakan paham sekuler. Kepemimpinan ini banyak ditentang oleh masyarakatnya sendiri terutama para cendekiawan dan juga ulama. Pada masa ini juga mendirikan pasukan militer dengan nama Brigade Cosscack dan juga Universitas Teknik yang melahirkan cendekiawancendekiawan muslim Iran. Walapun begitu karena sistem pemerintahan yang ditentang oleh masyarakat dan ulama karena mengadopsi pemerintahan barat dan bekerja sama dengan barat akhirnya dinasti ini 
runtuh oleh panglimanya sendiri yaitu Reza Syah Pahlevi. Reza pada saat menggulungkan dinasti Qajar dibantu oleh para ulama dan sangat mendukungya. Tetapi karena kepemipinanya yang otokrasi menjadikan ulama mundur dari pendukungnya yang pada akhirnya ketika putranya memimpin yang kurang kuat seperti halnya pendahulunya maka terjadi revolusi yang diprakarsai oleh para ulama yang disebut dengan Mullah dan menjadikan Iran menjadi republik dan menggunakan sistem pemerintahan Waliyatul faqih kepemimpinan tertinggi dipegang oleh Ulama.

\section{KESIMPULAN}

Sistem pemerintahan republik Iran menggunakan sistem waliyatul faqih akan tetapi dalam menjalankan pemerintahan juga menggunakan demokrasi ditandai dengan adanya trias politika yaitu adanya lembaga eksekutif, yudikatif dan legislative. Kepala pemerintahan dipegang oleh presiden yang dipilih oleh rakyat akan tetapi presiden ini kekuasaanya masih di bawah Mullah dan bisa diberhentikan oleh Mullah. Pemilihan umum juga dilakukan masyarakat dalam menentukan wakil rakyatnya di legislative yang menjabat selama 4 tahun. Kekuasaan Yudikatif yang tertinggi dipegang oleh mahkamah Agung yang dipilih oleh rahbah yang membawahi pengadilan tinggi propinsi dan pengadilan rendah kota.

\section{DAFTAR PUSTAKA}

Abdmolaei, S. (2013). (Re) Fashioning the Body Politic: Women and the Politics of Dress in the Islamic Republic of Iran (Doctoral dissertation, Concordia University).

Abidin, A. Z. (1977). Ilmu Poltik Islam III Sejarah Islam Dan Umatnya Sampai Sekarang (Perkembangan Dari Zaman Ke Zaman), Jakarta: Bulan Bintang.

Adib, M. N. Q. (2018). Arus Baru Politik Islam: Pluralism, Kontestasi, Dan

Demokratisasi, Maqashid: Jurnal Hukum Islam Vol. 1 No. 2

Asep, B. (2011).Trj Faiz, Tajul Milah, Post Islamisme Yogyakarta: Lkis.

Chehabi, H. E. (1991). Religion and Politics in Iran: How Theocratic Is the Islamic Republic?. Daedalus, 69-91.

Chehabi, H. E. (1991). Religion and Politics in Iran: How Theocratic Is the Islamic Republic?. Daedalus, 69-91.

Esposito, J. L. \& O'Voll, J. (1999). Trj. Rahmani Astuti, Demokrasi Di Negara-Negara Muslim: Problem Dan Prospek,Bandung: Mizan. 
Esposito, J. L. 1990. Trj Sahat Imamora, Islam Dan Pembangunan Jakarta: Renika Cipta.

Hamzah, A. \& Kazhim, M. (2007). Perang Dunia III Di Pelupuk Mata Iran Scenario Penghabisan, Jakarta :Cahaya Insan Suci.

Hefner, R. W. (2005). Remaking Muslim Politics, Pluralism, Contestation, and Democratitation. Princeton dan Oxford: Princeton University Press.

Hidayat, U. (2014). Politik Hukum Islam Dalam Sistem Hukum Tatanegara Republik Islam Iran, Asy-Syari'ah Vol. 16, No 2, Agustus.

Idhil akbar. (2017). Khalifah Islamiyah: antara konsep dan realitas kenegaraan (republic islam iran dan kerajaan islam arab Saudi), Journal of Government and Civil Society, Vol. 1, No. 1.

Ihsan, A. \& Panggabean, S. R. (2011). Demokrasi dan Kekecewaan, edisi digital, Jakarta: Yayasan Abad Demokrasi.

Kadir, A. (2015). Syiah Dan Politik: Studi Republik Islam Iran,Jurnal Politik Profetik Volume 5 Nomor 1.

Kiki, \& Fatoni, A. (2019). Program Pengembangan Nuklir Iran Dan Pengaruhnya Terhadap Masyarakat Iran (1957-2006 M), Jurnal Studi Sosial dan Politik, Vol. 3 No. 1.

Lapidus, I. M. (1999). Trj. Ghufron A Saadi, Sejarah Sosial Umat Islam, Bagian 3. Jakarta: Raja Grafindo Persada.

Lapidus, I. M. (1999). Trj. Ghufron A Saadi, Sejarah Sosial Umat Islam, Bagian 1-2. Jakarta: Raja Grafindo Persada.

Mikail, K. (2019). Sistem Politik Iran Kontemporer: Dari Westernisasi Hingga Islamisasi, Jurnal Intelektualita: Keislaman, Sosial, Dan Sains, Vol. 8, No. 2.

Nugroho, A. (2014). Pengaruh Pemikiran Isalm Revolusioner Ali Syari'ati Terhadap Iran, Profetika Jurnal Studi Islam, Vol. 15, No. 2.

Rais, M. (2018). Sejarah Perkembangan Islam Di Iran, Tasamuh: Jurnal Studi IslamVolume 10, Nomor 2.

Salehi-Isfahani, D. (2009). Poverty, inequality, and populist politics in Iran. The Journal of Economic Inequality, 7(1), 5-28.

Satori ,A. (2012). Sitem Pemerintahan Iran Modern konsep Waliyatul Faqih Imam Khoneini Sebagai Teologi Politik Dalam Relasi Agama Dan Demokrasi, Yogyakarta: Rausyan Fikr Institute.

Sjamsuddin, H. (1996). Metodologi Sejarah, Jakarta, Depdikbud.

Smith, B. B. (2007). Hard times in the lands of plenty: oil politics in Iran and Indonesia. Cornell University Press. 